\title{
SURVIVAL IN MARRIAGE IN THE PARAPLEGIC COUPLE: PSYCHOLOGICAL STUDY
}

\author{
By Amnon David, M.D. ${ }^{1}$ Samuel Gur, M.Sc., and \\ RAPHAEL RoZIN, M.D. \\ Laboratory of Physiology, Department of Obstetrics and Gynecology, and the Sir Ludwig \\ Guttmann Spinal Cord Injury Center, The Sheba Medical Center, Tel-Hashomer, Tel-Aviv \\ University School of Medicine, Israel
}

Abstract. In a study of sexual functions and marital relations in I6 couples involving a normal female and a paraplegic male, married following the injury, it was found that a major source of dissatisfaction on the part of the wives was their inability to become pregnant and bear children. Sexual relations were surprisingly of secondary importance. Common in all i6 couples was the almost total lack of knowledge on the part of the woman about the man's sexual capabilities and the effect of his injury on fertility. Premarital counselling seems to be of primary importance in assuring the survival of such marriages. It may be useful to suggest they have premarital experience. Later, counselling should include the importance and advantages of artificial insemination donor treatment as a solution to infertility.

Key words: Spinal cord injuries; psychological; family characteristics; adaptation.

\section{Introduction}

MARRIAGE, sex and the family have become in recent times the target of much criticism as people search for an answer of how to survive in marriage.

With regard to paraplegic couples, a number of studies on sexual function are found in the literature stressing the physical and physiological findings (Fitzpatrick, 1972; Griffith, et al., 1973), with a relative neglect of psychological considerations. What literature there is on the psychological aspects of sex in these couples deals with the injured person himself (Teal \& Atheston, 1975), and not, to the best of our knowledge, with his mate. In view of the uncertainty about whether marriage with a paraplegic can or cannot result in a normal family unit, we decided to examine the motivation, satisfactions and dissatisfactions of apparently normal women who married paraplegic men.

\section{Material and Methods}

The sample consisted of I 6 married couples in which the male partner had suffered a spinal cord injury before marriage. In all cases the lesion was located from $\mathrm{C}_{5}$ to $\mathrm{L}_{\mathrm{r}}$ : it was incomplete in three patients and complete in $\mathrm{I}_{3}$, two of whom had a lower neuron motor lesion. Erection occurred in eight of the I6 cases, mostly during catheterisation, and was full in three of them. In the cases with full erection, masturbation produced a slight emission of semen which was rich in prostatic fluid and contained a few spermatozoa, sometimes with retrograde ejaculation. Full erection was considered when the spouse reported she could introduce the penis fully into her vagina for some period of time, not necessarily leading to orgasm.

1 Present address: Department of OB/GYN, Carmel Hospital, Haifa, Israel.

Address for Offprints:Prof. A. David, Director, Department of Obstetrics and Gynecology, Carmel Hospital, Haifa, Israel. 
The clinical study of these cases is presented in detail elsewhere (David et al., I976).

The wives ranged in age between 20 and $3 \mathrm{I}$, with an average of 24.6 . The couples had been married from I to 4 years, with the exception of one who had been married for 12 years. Fifteen of the women were born in Israel and one was born in Holland. All had completed elementary school and ten had attended college. Six women did not work, three were secretaries, four were teachers, one was a nurse's aid, one a laboratory technician and one a business manager. All the women reported normal sexual development, including the menarche, breast development and appearance of secondary sex characteristics.

Each wife was interviewed individually on a two-part questionnaire. Onethird of the questions were 'yes/no' type to obtain demographic information. The remaining two-thirds were open-ended questions about the following factors: sexual and psychosocial development; sources of sex education, including parents, friends, school, books; knowledge of her husband's sexual capabilities and function and their fertility as a couple; her expectation from the marriage; the degree of fulfilment of her various life goals; and her reaction to artificial insemination donor treatment (A.I.D.) and adoption.

\section{Results and Comments}

Despite the fact that all the women reported normal sexual development, the interview revealed a late sexual awakening in five of the 16 , between ages 17 and 20 when compared to a control group of similar age and background. Time of sexual awakening was defined when the woman was involved in sexual relationship even without full intercourse. These five made comments like...' I always tried to escape from dealing with sexual affairs' ... 'I was not attracted by sex' . . 'I am afraid of the male organ'; when asked: 'At what age did you start having sexual external or internal contacts ?' ... 'Were you attracted by the male sex ?' . . . Most of the I6 women had a fairly good knowledge about sex and received a basic sex education from either their parents or at school. But, surprisingly, except for two who lived with their husbands before marriage, none of them really knew about their future husband's sexual functioning until after marriage. They had not been informed of the specific sexual disability involved and especially of its impact on fertility.

Their expectations of marriage were similar to those of any other normal married couple as concerns love, home, mutual understanding and acceptance, social and economic security. However, in most of the cases these expectations were not met, especially in regard to sexual enjoyment and bearing children. In eight of the cases sexual activity consisted of attempts at sexual intercourse where the women took advantage of her husband's erection for purpose of coitus; the duration of these events was not clear but was generally reported to be of 'very short duration, which permits only the introducing of the penis, then it would immediately retract'. The sexual drive seemed to decrease significantly with years of marriage. When asked: 'Do you enjoy sex intercourse with your husband ?' the woman married for 12 years stated 'Can you imagine all the possible secretions, smells and other things one has to suffer in order to get a very small amount of sexual gratification?'

The fact that only two of the I6 couples are in the process of divorce is not an indication of the happiness of the others as family units. These two women did not live with their spouses prior to marriage and were not part of the five women 
with late sexual awakening. All but one of the women are native-born Israeli, making them part of the population that places a very high value on family and children (Nerya, 1974). Despite this emphasis, there is almost no awareness in Israel about premarital investigation of the fertility state. The interviews revealed that seven of the $\mathrm{I} 6$ couples had considered divorce at some time but decided 'to suffer and survive together'. Apparently the local religious and social pressures work strongly against divorce. The security of economic support ensuing from the husband's disability may also bolster their decision to stay together. Comarr (I962) reported in the United States that from a marriage rate among paraplegics of 26 per cent, 2 I per cent were divorced. However, this must be seen against the 26 per cent divorce rate in the general U.S. population for that year. In Great Britain, Guttmann (1964) reported a divorce rate among paraplegics of 7.3 per cent compared to a national rate of I per cent. In Israel in 1974 the national divorce rate was 0.9 per cent of which only a very small insignificant number were paraplegic couples which reaches 3 to 5 per cent.

A major source of dissatisfaction on the part of the wives was found to be their inability to become pregnant and bear children, which they view as a personal failure. They all responded positively to the suggestion of A.I.D., feeling that having a child would compensate for the lack of regular sexual activity. We found in a previous study that providing these women with the possibility of having children by A.I.D. treatment served to strengthen the union of the couple (David \& Avidan, 1976). During the present study the couples were informed of the possibility of having a baby either by adoption or by A.I.D.; they were counselled about the advantages of A.I.D., including the feelings of motherhood and shared genetic characteristics, at least on the part of the mother. Three of the women conceived by A.I.D. during the study and exhibited a definite change of mood and attitude toward life. All the wives viewed adoption as 'another sacrifice' to their husbands. In fact the reaction of the husbands to A.I.D. v. adoption was rather surprising, and may be explained by the lack of information given to these patients concerning their sexual functions, including their possibility to procreate. Most of them were against A.I.D. at the beginning of counselling. They were all seeking medical treatment or a technique for collecting their own sperm (David et al., 1976), and in the event that this was not possible they preferred adoption so as to equalise the share of parenthood. However, they changed their minds when it was explained that A.I.D. would permit the wife to express her femininity and thereby strengthen the family unit.

\section{Conclusions}

A number of conclusions can be drawn from this study. Although the paraplegic couple is not meeting the usual standards of a happy sexual union, its survival can be better assured if correct information about the sexual potential of the future husband is revealed before marriage. In fact, the two women who lived with their husbands prior to marriage cope better with such a life and it seems that their marriages are more likely to survive than the other I4. In addition, the disabled patient should learn more about the motivations and goals of his future wife and inform her of his deficient sexual functions and possible infertility. As this study showed, one of the major problems among these couples is not the inability to have normal coitus, but rather infertility, which appeared as the main reason for considering divorce.

Premarital sexual counselling should be given by a qualified body, and should relate to the specific needs of each couple. It may also be useful to suggest that the 
couple have premarital experience. Counselling after marriage should include the importance and advantages of A.I.D. as a solution to infertility until better results can be obtained with the rectal electroejaculation technique, enabling collection of sperm and possible husband artificial insemination (David et al., 1976).

Further research is required on methods of counselling these couples and on the motivations of women who marry disabled men. In addition, follow-up studies should be carried out on the survival of these family units after counselling.

\section{RÉSUMÉ}

Les fonctions sexuelles et les rapports maritaux de I6 couples comprenant une femme en bonne santé et marié à un homme paraplegique ont ete le sujet de cette etude. Le marriage dans tous des cas a eu lieu apres l'accident du mari.

Une des causes principales de mecontentement et de disatisfaction de la part des epouses se revele etre leur impossibilite d'etre enceinte et de devenir des futures meres, l'importance des rapports sexuels se trouvent etre, contrairement a notre premiere pensee d'importance secondaire. Il a ete egalement note que les I 6 epouses manquaient completement d'informations concernant les capacites sexuelles de leur mari et de plus n'avaient aucune notion de l'effet de leur pathologie sur leur fertilite.

Il semble qu'un conseil premarital dans tous ces cas est d'importance capitale qui essaiera et saura maintenir ces marriage. Une autre conclusion de cette etude est l'avantage de conseiller a ces couples un essai de vie en commun avant leur marriage. Plus tard il serait avantageux de mettre en valeur l'importance et l'avantage de l'insemination artificielle comme solution de leur infertilite.

\section{ZUSAMMENFASSUNG}

In einer Studie der Sexualfunktionen und Ehebeziehungen in I6 Paaren, die aus einer gesunden frau und einen paraplegischem Mann bestanden, und die nach der Verletzung heirateten, wurde festgestellt, dass eine Hauptquelle der fehlenden Befriedigung auf der seite der Frau ihr Unvermögen war, schwanger zu werden und Kinder zu gebaeren. Sexualle Beziehungen waren erstaunlicherweise von zweitrangiger Wichtigkeit.

Gemeinsam war bei allen I6 paaren fast voellige Unkenntnis der frau bezüglich der sexuellen Faehigkeiten ihres Ehepartners und der Folgen seiner Verletzung auf seine Fruchtbarkeit. Voreheliche Beratung scheint von hoechster Wichtickeit für das bestehen solcher Ehen zu sein.

Man sollte solchen Paaren zu vorehelichen Erfahrungen raten. Später sollte die Beratung die Wichtigkeit und vorteile der Kuenstlichen Befruchtung durch einen Spender als Loesung des Fruchtbarkeits Problems unterstreichen.

Acknowledgement. The authors are indebted to Mrs Frances Zetland for her help in the preparation of the manuscript.

\section{REFERENCES}

ComarR, A. E. (1962). Marriage and divorce among patients with spinal cord injury. I through V. Proc. of the Veterans Administration Spinal Cord Injury Conference, II, I63-215.

David, A. \& Avidan, D. (1976). Artificial insemination donor: clinical and psychologic aspects. Fertil. Steril. 21, 528-532.

David, A., OHRY, A. \& RozIn, R. (I977). Spinal cord injuries: male infertility aspects. Paraplegia, II, II-I4.

FitzPATRICK, W. F. (I972). Sexual function in the paraplegic patient. Arch. Phys. Med. Rehab. 55, 22 I-227.

Griffith, E. R., Tomko, M. A. \& Timms, R. J. (1973). Sexual function in spinal cord injury patients: a review. Arch. Phys. Med. Rehab. 54, 534-543.

GuttmanN, W. L. (1964). Married life of paraplegics and tetraplegics. Paraplegia, 2, I82-I88.

Nerya, R. (1974). The Jewish attitude towards sexuality and family life. In: Abstracts of the and International Symposium on Sex Education, Tel-Aviv, p. 40.

TeAL J. C. \& Atheston, G. T. (1975). Sexuality and spinal cord injury: some psychosocial considerations. Arch. Phys. Med. Rehab. 56, 264-268. 